\title{
PERLINDUNGAN HUKUM DAN IMPLEMENTASI DOKTRIN FAIR USE TERHADAP COSTUME PLAY (COSPLAY) DALAM HAK CIPTA DAN DESAIN INDUSTRI
}

\section{Galih Dwi Ramadhan \\ Magister Hukum Fakultas Hukum Universitas Islam Indonesia}

Contact: gdramadhan@gmail.com

Diterima: 7 November 2021

Direvisi: 20 November 2021

Disetujui: 7 Desember 2021

Hak Cipta: (C)2018

Halaman: $13-26$

\begin{abstract}
Cosplay 'Costume \& Play' is a term that describes a popculture phenomenon about a person's creativity by creating and using a costume and its accessories to play a role based on references to fictional characters from comic books, animated films, and video games. Costumes and accessories used for cosplay are the work of human intellectuals which should be protected by intellectual property rights because in practice many parties get financial benefits from cosplay activities. There is no explicit regulation on the protection of intellectual works, especially Copyright and Industrial Design Rights for cosplay costumes and accessories. A normative juridical study is needed in understanding the legal provisions on cosplay using the Copyright Law and the Industrial Design Law.
\end{abstract}

Keywords: Costume Play (Cosplay), Intellectual Property Rights, Copyright, Industrial Design 


\section{PENDAHULUAN}

Seorang manusia memimiki akal pikiran atau yang juga dikenal dengan istilah 'intelektual'. Melalui intelektual, seorang manusia dapat menciptakan suatu hal khususnya sebuah karya. Karya-karya yang diciptakan, dilahirkan ataupun dihasilkan atas kemampuan intelektual seorang manusia melalui tenaga, daya, pikiran hingga modal keuangan dalam menghadirkan sebuah karya, sehingga sudah sewajarnya jika karya tersebut dapat diamankan dengan menumbuhkembangkan sistem perlindungan hukum atas kekayaan yang dimiliki karya tersebut yang dikenal sebagai sistem Hak Kekayaan Intelektual (HKI).

HKI menjadi sebuah bagian yang amat penting dalam perkembangan ekonomi nasional dan internasional (DJKI, 2013). HKI merupakan sebuah hak yang bersifat intangible dan eksklusif yang memiliki nilai ekonomi bagi pemilik usaha yang diberikan kepada seseorang untuk menghargai karya asli dari orang tersebut dan digunakan sebagai tanda kepemilikan hak tersebut serta menjadi sebuah hak untuk menikmati secara ekonomis atas hasil dari suatu kreativitas karya intelektual seorang manusia.

Kekayaan intelektual merujuk kepada kreasi pikiran: penemuan, karya sastra dan artistic, dan simbol-simbol, nama, dan gambar yang digunakan dalam perdagangan. Pengelompokan HKI dikategorikan sebagai Hak Cipta yang terdiri dari hak cipta dan hak terkait dan Hak kekayaan industri yang berupa paten, merek, desain industri, desain tata letak sirkuit terpadu, rahasia dagang dan varietas tanaman.

Salah satu contoh dari karya hasil intelektual manusia ialah sebuah karya yang berupa sebuah pakaian atau kostum yang dilengkapi dengan berbagai aksesoris yang menunjang estetika untuk sebuah karya pakaian. Dalam menciptakan sebuah karya yang berbentuk sebuah pakaian atau kostum, intelektual manusia memulai proses penciptaan tersebut dengan membuat rancangan pakaian atau kostum tersebut yang dituangkan kedalam bentuk media alat tulis-menggambar secara cetak ataupun secara digital. Berangkat dari proses rancangan pakaian atau kostum berserta aksesoris yang melengkapi dalam sebuah bentuk gambar 2 dimensi maupun 3 dimensi, setelah itu dilanjut dengan melakukan peniruan ataupun adaptasi kedalam bentuk sebuah pakaian yang berbentuk 3 dimensi dan dapat digunakan oleh manusia.

Karya intelektual manusia yang berupa gambar rancangan pakaian atau kostum serta karya bentuk jadi dari pakaian atau kostum sepatutnya mendapatkan perlindungan oleh hukum dalam bentuk perlindungan HKI. Secara umum, karya yang berbentuk sebuah gambar merupakan objek hak cipta dan juga pakaian atau kostum merupakan objek dari desain industri apabila pakaian atau kostum tersebut diperuntukan untuk diproduksi secara massif sebagai kegiatan industri.

Perihal ketentuan aturan terhadap Hak Cipta beserta Hak Terkait di Indonesia diatur dalam Undang-Undang No. 28 Tahun 2014 tentang Hak Cipta. Hak cipta yang 
merupakan hak ekslusif pencipta atau pemegang hak cipta untuk mengatur, mengumumkan atau memperbanyak penggunaan hasil penuangan gagasan, hasil ciptaan atau informasi tertentu atau memberi izin. Hak cipta menjadi bagian dari kekayaan intelektual yang memiliki ruang lingkup objek dilindungi paling luas, karena mencakup ilmu pengetahuan, seni dan sastra serta mencakup program komputer.

Ketentuan Hak Desain Industri di Indonesia diatur dalam Undang-Undang No. 31 Tahun 2000 tentang Desain Industri. Desain industri merupakan hak ekslusif yang diberikan oleh negara kepada pendesain atas hasil kreasinya untuk selama waktu tertentu melaksanakan sendiri, atau memberikan persetujuannya kepada pihak lain untuk melaksanakan hak tersebut. Desain industri yang dimaksud ialah suatu kreasi tentang bentuk, konfigurasi atau kompisisi garis atau warna, atau garis dan warna, atau gabungan daripadanya yang berbentuk tiga dimensi atau dua dimensi yang memberikan kesan estetis dan dapat diwujudkan dalam pola tiga dimensi atau dimensi untuk menghasilkan suatu produk, barang, komoditas industri atau kerajinan tangan.

Pada masa ini, terdapat sebuah fenomena Pop-Culture yang menunjukan kreatifitas intelektual manusia dalam bentuk berpakaian dengan menggunakan kostumkostum berserta aksesorisnya yang unik dan menarik secara visual yang diadaptasi dari berbagai desain karakter dari tokohtokoh fiksi dalam sebuah buku cerita atau komik, film animasi hingga video game. Fenomena Pop-Culture tersebut disebut dengan istilah 'Cosplay'.
Cosplay merupakan sebuah singkatan dari Costume \& Play yang dimaknai sebagai sebuah kegiatan bermain dengan kostum. Kegiatan bermain dengan kostum merupakan sebuah fenomena yang terjadi dimasyarakat modern dan menjadi sebuah budaya yang populer, seperti halnya yang terjadi di negara barat dengan budaya menggunakan kostum pada saat perayaan malam Hallowen dan berbagai acara lainnya yang identic dengan menggunakan sebuah kostum untuk memeriahkan sebuah acara.

Dalam hal ini, kostum yang digunakan membutuhkan sebuah pakaian dan aksesoris untuk menjadi karakter tertentu dan orang yang berkostum tersebut bermain peran sesuai dengan karakter yang ditirukan dan menjadi sebuah kegiatan (Wang, 2010).

Kegiatan bermain dengan kostum menjadi sebuah budaya populer di Jepang sejak awal tahun 2000 disaat masa ke-emasan atas karya buku komik/manga dan animasi di Jepang. Pada saat itu kegiatan bermain dengan kostum untuk menirukan sebuah karakter fiksi dari berbagai karya buku komik/manga dan animasi baik secara visual berpakaian hingga kepribadian, istilah kegiatan tersebut mulai dikenal dengan istilah 'Cosplay' dan untuk orang yang melakukannya disebut dengan istilah 'Cosplayer'.

Cosplay merupakan prilaku dan tindakan seseorang yang mengenakan pakaian lengkap dengan aksesoris dan rias wajah semirip mungkin dengan karakter fiksi yang ditirukan secara visual maupun kepribadian karakter fiksi tersebut yang ditampilkan dalam bentuk yang terbaik (Bonnichisen, 
2011). Cosplay menjadi sebuah alat praktis yang bergunsi sebagai peran tertenti yang dimana para pemakai kostum bisa merasa menjadi peran yang dibutuhkan serta bisa menjadi pribadi yang diinginkan (Fukiko, 2008). Secara singkatnya, cosplay merupakan hasil karya seorang penggemar yang melalukan fandoming terhadap karakter fiksi yang digemarinya (Brown, 1997).

Dimasa sekarang ini, Cosplay merupakan sebuah hal yang lumrah dan menjadi sebuah bagian dari sebuah kebudayaan yang populer (Pop-Culture) seiring perkembangan karya-karya fiksi dalam bentuk buku komik, film animasi dan video games. Secara singkat, Cosplay merupakan manifestasi dari sebuah karya. Semakin berkembangnya karya-karya tersebut maka semakin mempengaruhi perkembang terhadap kegiatan cosplay (Madonia, 2016).

Cosplay yang menjadi sebuah Pop-Culture karena para penggemar cosplay atau yang disebut sebagai cosplayer menjadikan kegiatan cosplay sebagai sebuah saluran untuk berekspresi diri dalam bentuk yang kreatif untuk dipetunjukan kepada umum. Aspek kreatif dalam Cosplay ialah dimana seorang cosplayer harus menyediakan atau membuat seperangkat pakaian kostum dan aksesoris dan bertata-rias wajah berdasarkan karakter yang ingin diperankan/ditiru yang kemudian dipertunjukan secara umum secara langsung ataupun media digital-internet.

Fenomena kegiatan Cosplay di masyarakat sebagai sebuah Pop-Culture yang pada awalnya dipandang sebagai sebuah hobi kemudian saat ini dapat menjadi sebuah profesi. Profesi yang dimaksud ialah menjadi seorang artis-model ataupun sebagai penyedia atau jasa pembuatan kostum dan aksesoris hingga jual-beli untuk sebuah kostum dan aksesoris berdasarkan karakter tokoh fiksi yang diinginkan. Dalam hal ini, Cosplay sendiri terdiri dari sebuah kostum dan aksesoris yang saling melengkapi. Kostum dan aksesoris tersebut merupakan sebuah karya dari kreatifitas intelektual seseorang, karena dalam membuatnya membutuhkan waktu, pikiran, tenaga dan modal untuk menciptakan kostum dan aksesoris berdasarkan refrensi sebuah tokoh/karakter fiksi dari buku komik, film animasi dan/atau video game.

Fenomena cosplay tersebut menimbulkan berbagai isu dan polemic terhadap pemahaman dan pandangan masyarakat terhadap cosplay sebagai sebuah tindakan pelanggaran atas hak kekayaan intelektual yang memberikan dampak secara ekonomi dan moral atas berbagai kegiatan saat ini banyak melibatkan kegiatan cosplay yang dikomersialisasikan secara umum dan terang-terangan.

Kurangnya kajian terhadap cosplay dalam sudut pandang hak kekayaan intelektual menjadikan pemahaman masyarakat atas cosplay hanya berdasarkan pemahaman secara umum tanpa ada pemahaman yang lebih mendalam terkait hak kekayaan intelektualnya. Hal tersebutlah yang menjadi tujuan dari penulis dalam membuat karya tulis ini yaitu untuk memberikan pemahaman yang lebih mendalam tentang Cosplay dengan menggunakan kajian hak kekayaan intelektual serta hukum nasional (Hak Cipta dan Desain Industri) yang dapat digunakan untuk memberikan perlindungan 
terhadap Cosplay.

Sebelumnya terdapat sebuah karya tulis serupa yang mengkaji tentang Cosplay dari sudut pandang Hak Cipta yaitu karya tulis dari Restie Santya Kartika yang berjudul perlindungan hukum terhadap Costume Play (Cosplay) atas hak cipta animasi dan karakter komik (Kartika, 2017). Perbedaan karya tulis milik Restie Sentya dengan karya tulis milik saya ini terletak pada kajian yang saya lakukan tidak hanya mengkaji Costume Play (Cosplay) menggunakan Hak Cipta saja, melainkan juga menggunakan kajian Hak desain Industri serta mengkaji implementasi doktrin fair use terhadap Costume Play (Cosplay) yang dipandang sebagai sebuah pop-culture di masyarakat.

\section{RUMUSAN MASALAH}

Berdasarkan latar belakang masalah diatas, maka rumusan masalah dalam karya tulis ini ialah: 1) Bagaimana Perlindungan Hukum terhadap Costume Play (Cosplay) dalam Undang-Undang Hak Cipta dan Undang-Undang Desain Industri?; 2) Bagaimana implementasi doktrin Fair Sse terhadap Costume Play (Cosplay)?

\section{TUJUAN PENELITIAN}

Sesuai dengan rumusan masalah sebelumnya, maka tujuan dari penelitian ini ialah: 1) Mengetahui bentuk perlindungan hukum terhadap Costume Play (Cosplay) dalam UU Hak Cipta dan UU Desain Industri; 2) Mengetahui implementasi doktrin Fair Sse terhadap Costume Play (Cosplay).

\section{HASIL DAN PEMBAHASAN Cosplay Dalam UU Hak Cipta}

Hak cipta adalah hak ekslusif pencipta yang timbul secara otomatis berdasarkan prinsip deklratif setelah suatu ciptaan diwujudkan dalam bentuk nyata tanpa mengurangi pembatasan sesuai dengan ketentuan peraturan perundang-undangan. Ciptaan merupakan setiap hasil karya cipta di bidang ilmu pengetahuan, seni, dan sastra yang dihasilkan atas inspirasi, kemampuan, pikiran, imajinasi, kecekatan, keterampilan atau keahlian yang diekspresikan dalam bentuk nyata.

Ciptaan yang dilindungi berdasarkan Pasal 40 ayat (1) UU Hak Cipta meliputi Ciptaan dalam bidang ilmu pengetahuan, seni, dan sastra dapat dibedakan dalam beberapa jenis ciptaan yang dapat dilihat berdasarkan jenis yang terdapat pada aplikasi hak cipta berupa karya tulis, karya lainnya, karya seni, karya audio visual, karya drama \& koreografi, karya fotografi, karya komposisi music, karya rekaman (DJKI, Modul Kekayaan intelektual Hak Cipta, 2020).

Pasal 40: (1) Ciptaan yang dilindungi meliputi Ciptaan dalam bidang ilmu pengetahuan, seni, dan sastra, terdiri atas:

a. Buku, pamphlet, perwajahan karya tulis yang diterbitkan, dan semua hasil karya tulis lainnya;

b. Ceramah, kuliah, pidato, dan Ciptaan sejenis lainnya;

c. Alat peraga yang dibuat untuk kepentingan pendidikan dan ilmu pengetahuan;

d. Lagu dan/atau music dengan atau tanpa teks;

e. Drama, drama musical, tari, koreografi, pewayangan, dan pantonim; 
f. Karya seni rupa dalam segala bentuk seperti lukisan, gambar, ukiran, kaligrafi, seni pahat, patung, atau kolase;

g. Karya seni terapan;

h. Karya arsitektur;

i. Peta;

j. Karya seni batik atau seni motif lain;

k. Karya fotografi;

l. Protret;

m. Karya sinematografi;

n. Terjemahan, tafsir, saduran, bunga rampai, basis data, adaptasi aransemen modifikasi dan karya lain dari hasil transformasi;

o. Terjemahan, adaptasi, aransemen, transformasi, atau modifikasi ekspresi budaya tradisional;

p. Kompilasi Ciptaan atau data, baik dalam format yang dapat dibaca dengan Program Komputer maupun media lainnya;

q. Kompilasi ekspresi budaya tradisional selama kompilasi tersebut merupakan karya yang asli;permainan video; dan

r. Program computer.

Secara ekplisit, karya sebuah kostum ataupun cosplay tidak di cantumkan dalam Pasal 40 ayat 1 UU Hak Cipta dalam lingkup Objek Hakc Cipta. Apabila dipahami lebih lanjut terkait proses pembuatan cosplay, pada proses awal pembuatan kostum cosplay terjadi dengan melakukan adaptasi sebuah gambar atas desain karakter tertentu. Dalam hal ini, terdapat sebuah rancangan/sketsa desain awal sebuah kostum \& aksesoris yang dituangkan kedalam media konvensional ataupun media digital. Gambar yang merupakan objek hak cipta yang tercantum dalam pasal 40 ayat 1 (f). f. Karya seni rupa dalam segala bentuk seperti lukisan, gambar, ukiran, kaligrafi, seni pahat, patung, atau kolase;

Penjelasan huruf $f$, yang dimaksud dengan "gambar" antara lain, motif, diagram, sketsa, logo, unsur-unsur warna dan bentuk huruf indah.

Proses pembuatan kostum dan aksesoris Cosplay berawal dari proses adaptasi dari sebuah rancangan/sketsa kostum atau desain karakter yang tertuang dalam sebuah gambar. Sehingga dalam hal ini cosplay dapat menjadi sebuah adaptasi atas mengalihwujudkan suatu ciptaan menjadi bentuk lain dalam hal ini dari gambar rancangan desain kostum atau aksesoris menjadi kostum atau aksesoris secara fisik dan dapat digunakan oleh manusia. Ketentuan terkait objek hak cipta atas tindakan adaptasi sebuah karya ciptaan diatur dalam pasal 40 ayat $1(\mathrm{n})$

n. Terjemahan, tafsir, saduran, bunga rampai, basis data, adaptasi aransemen modifikasi dan karya lain dari hasil transformasi;

Penjelasan huruf $n$ tentang adaptasi, yang dimaksud dengan "adaptasi" adalah mengalihwujudkan suatu Ciptaan menjadi bentuk lain. Sebagai contoh dari buku menjadi film.

Cosplay tidaknya hanya berupa sebuah kostum dan aksesoris yang diciptakan dengan bahan utama kain - kulit yang merupakan bahan-bahan yang lazim dan umum digunakan sebagai pakaian seharihari, tetapi dalam kostum dan aksesoris 
yang diperuntukan untuk Cosplay beberapa menggunkan bahan yang non kain - kulit yaitu seperti bahan busa keras (eva foam), busa kasur, aluminium/kuningan, cairan latex - silicon, dan berbagai bahan material lainnya yang kemudian diberi pewarna menggunakan berbagai jenis pernua. Seluruh proses pengerjaan kostum dan aksesoris cosplay yang berbahan non kainkulit, pada keseluruhan prosesnya dikerjakan dengan menggunakan tangan manusia (handmade) yang diberikan sentuhan berupa motif ataupun ornamen pada permukaan kostum atau aksesoris tersebut tanpa bantuan sebuah mesin, proses penciptaan tersebut seperti halnya dalam proses pembuatan karya seni terapan. Ketentuan terkait karya seni terapan sebagai objek hak cipta diatur dalam Pasal 40 ayat 1 (g)

\section{g. karya seni terapan}

Penjelasan huruf $g$ tentang karya seni terapan, yang dimaksud dengan "karya seni terapan" adalah karya seni rupa yang dibuat dengan menerapkan seni pada suatu produk sehingga memiliki kesan estetis dalam memiliki kesan estetis dalam memenuhi kebutuhan praktis, antara lain penggunaan gambar, motif, atau ornament pada suatu produk.

Berdasarkan penjelasan tersebut di atas. Walaupun Kostum tidak disebutkan secara eksplisit sebagai objek yang dilindungi oleh UU Hak Cipta, tetapi Kostum beserta aksesoris yang melengkapinya khususnya Cosplay dapat dilindungi oleh hak cipta dan tergolong sebagai objek hak cipta, jika memenuhi ketentuan sebagai 'karya seni terapan' atau 'adaptasi ciptaan' yang diatur dalam Pasal 40 ayat 1 (huruf $n$ \& g) dan mendapatkan masa perlindungan hak cipta seumur hidup penciptanya selam lebih dari 70 tahun dengan ketentuan harus orisinil atau telah mendapatkan izin dari pihak terkait sebagai pemilik atau pemegang lisensi untuk dapat diadaptasi.

Cosplay sebagai 'Karya Seni Terapan', jika Cosplay tersebut di ciptakan dengan menggunakan bahan utama non kain-kulit seperti yang telah disebutkan sebelumnya serta pada permukaan kostum dan aksesoris cosplay terdapat motif atau ornament yang keseluruhan prosesnya dikerjakan dengan tangan manusia tanpa bantuan mesin (Handmade)

Gambar merupakan objek hak cipta yang secara eksplisit disebutkan dalam pasal 40 ayat 1 (f). Perihal Cosplay sebagai 'Adaptasi Ciptaan', kostum dan aksesoris cosplay diciptakan dengan mengadaptasi sebuah gambar rancangan/sketsa kostum dan aksesoris yang dapat berupa gambar desain karakter tokoh-tokoh fiksi milik karya orang lain atau karya orisinil yang dituangkan kedalam media cetak atau digital yang digunakan pembuat cosplay sebagai gambar refrensi mereka untuk menciptakan sebuah kostum dan aksesoris seusai dengan gambar rancangan/sketsa yang diadaptasi.

\section{Cosplay Dalam UU Desain Industri}

Desain industri atau desain produk adalah salah satu cabang ilmu desain yang mempelajari aspek-aspek yang berkaitan dengan perancangan alat atau produk komoditi yang digunakan dalam kehidupan sehari-hari. Komoditi tersebut harus dapat diperbanyak atau diproduksi dalam jumlah 
tertentu. Perbanyakan jumlah barang tersebut harus mengikuti kaidah industri dimana setiap barang yang dibuat harus sama persis bentuknya (konsisten) satu sama lain baik yang dihasilkan oleh mesin (industri manufaktur) maupun tangan (industri kerajinan) (DJKI, Modul Kekayaan intelektual Lanjutan, 2020).

Pengguna desain adalah manusia, maka desain dituntut untuk mampu memenuhi kebutuhan pengguna baik kebutuhan fisik maupun psikis. Desain harus dapat memenuhi syarat fungsional, nyaman, aman, berdaya guna (efektif) dan bernilai guna (efisien). Secara psikis, desain juga dituntut mampu memberikan rasa tentram, percaya diri, kejelasan jati diri, dan kesenangan. Singkatnya, desain produk harus dapat memberikan atau menambah pengalaman estetis bagi penggunanya (Zainuddin, 2010).

Desain industri yang mengandung aspek rekayasa (keteknikan) yang dominan akan menuntut pengungkaan estetis yang lebih lugas dan praktis dibandingkan dengan desain industri seperti kerajinan atau fesyen yang lebih menonjolkan aspek daya tarik visual melalui gaya - style (DJKI, Modul Kekayaan intelektual Lanjutan, 2020).

Desain industri harus memiliki daya tarik visual namun desain industri berbeda dengan karya seni. Desain industri diciptakan dengan motivasi untuk mendapatkan keuntungan ekonomi ketika barang tersebut diproduksi masal dan dibeli oleh konsumen.

Menurut UU Desain Industri dijelaskan bahwa desain industri adalah suatu kreasi tentang bentuk, konfigurasi, atau komposisi garis atau warna, atau garis dan warna, atau garis dan warna, atau gabungan daripadanya yang berbentuk tiga dimensi atau dua dimensi yang memberikan kesan estetis dan dapat diwujudkan dalam pola tiga dimensi atau dua dimensi serta dapat dipakai untuk menghasilkan suatu produk, barang, komoditas industri, atau kerajinan tangan.

Kreasi merupakan upaya manusia dari mulai ide hingga tercipta menjadi karya yang memiliki ciri khas tertentu dibandingkan dengan yang ada sebelumnya. Kreasi muncul karena kemampuan manusia dalam berimajinasi atau menggali ide baru dimana kualitas kreasi dikenal dengan istilah kreativitas (Tabrani, 2005). Kreasikresi yang dapat dilindungi menurut UU Desain Industri dijelaskan sebagai berikut:

\section{- Bentuk:}

Bentuk merupakan kesan visual yang dirasakan secara 3 dimensi suatu objek tertentu yang diterapkan ke dalam desain. Menurut WIPO (World Intellectual Property Organization) bentuk merupakan wujud benda yang memiliki panjang, lebar dan tinggi.

- Konfigurasi

Kenfigurasa yang merupakan susunan dari beberapa eleman benda yang mementuk kombinasi visual tertentu. Desain dapat terbentuk dari kombinasi beberapa elemen-elemen visual sehingga menciptakan bentuk 3 dimensi yang baru.

- Komposisi garis

Komposisi gari ialah kreasi 2 dimensi 
(hanya terdiri dari panjang dan lebar dan tidak memiliki kedalaman atau ketinggian) yang merupakan pola garis yang ditempatkan pada permukaan produk.

\section{- Komposisi warna}

Komposisi warna adalah kreasi yang terdiri dari susunan dua atau lebih warna yang membuk poa sedemikian rupa pada suatu permukaan benda .

- Kombinasi dari elemen bentuk, warna dan garis

Kombinasi ialah kumpulan dari berbagai macam elemen antara bentuk dengan warna, bentuk dengan garis atau bentuk dengan warna dan garis. Dengan melakukan pengaturan komposisi tertentu, pendesain dapat menciptakan kombinasi yang menghasilkan kesan indah.

Perihal keterkaitan desain industri dengan cosplay, dalam hal ini pakaian ataupun kostum dan aksesoris yang melengkapinya dapat diklasifikasikan sebagai desain industri berdasarkan "Locarno Agreement" ke dalam produk pakaian wanita dan pakaian laki-laki.

- Sub-kelas 02-01: pakaian dalam, pakaian dalam wanita, korset, bra, pakaian malam;

- Sub-kelas 02-02: pakaian (garments);

- Sub-kelas 02-03: tutup kepala;

- Sub-kelas 02-04: sepatu sandal dan sejenisnya, kaos kaki dan stoking;

- Sub-kelas 02-05: dasi, selendang, syal dan sapu tangan

- Sub-kelas 02-06: sarung tangan

- Sub kelas 02-07: Pakaian (haberdashery) dan aksesoris pakaian
- Sub kelas 02-99: rupa-rupa
(miscellaneous)

Pada umumnya kostum dan aksesoris yang diperuntukan untuk kegiatan cosplay berbahan dasar kain - kulit, walaupun di sisi lain juga terdapat cosplay yang menggunakan bahan non kain - kulit. Terlepas dari bahan yang digunakan dalam kostum dan aksesoris cosplay, perpaduan kostum dan aksesoris cosplay dapat tergolong sebagai objek kreasi yang dilindungi oleh UU Desain Industri sebagai kreasi 'kombinasi bentuk, warna dan garis'.

Kostum dan aksesoris cosplay dalam praktiknya merupakan kumpulan dan kombinasi dalam bentuk pakaian pada umumnya atau berbentuk layaknya sebuah armor/pakaian perang hingga berbentuk monster yang memiliki aspek daya tarik visual kedalam sebuah bentuk yang memiliki volume panjang, lebar dan tinggi. kostum dan aksesoris cosplay juga mimiliki aspek perwarnaan dan garis yang beragam pada permukaannya sesuai dengan refrensi yang digunakan.

Apabila kostum dan aksesoris cosplay ingin mendapatkan perlindungan dari Desain industri, maka kostum dan aksesoris cosplay harus menjadi sebuah komoditi yang dapat diperbanyak atau diproduksi dalam jumlah tertentu dengan ketentuan disetiap produksinya dapat dibuat dengan konsisten dalam bentuk dan hasil jadi antara produk yang lainnya baik dihasilkan oleh mesin (industri manufaktur) maupun tangan (industri kerajinan). Serta harus memiliki aspek kebaharuan (novelty) dengan catatan jika pada tanggal penerimaan permohonan pendaftaran 
kostum dan aksesoris coslayh sebagai sebuah desain industri tersebut tidak sama dengan pengungkapan desain industri yang telah ada sebelumnya dan tidak bertentangan dengan peraturan perundangundangan yang berlaku, ketertiban umum, agama, atau kesusilaan.

Dengan didapatkan perlindungan desain industri atas sebuah kostum dan aksesoris cosplay, maka pemegang hak desain industri memiliki hak ekslusif untuk melaksanakan hak yang dimilikinya dan untuk melarang orang lain tanpa persetujuannya membuat, memakai, menjual, mengimpor, mengekspor dan/atau mengedarkan produk-produk terkait.

Dalam praktiknya, hanya kostum dan aksesoris cosplay yang berbahan dasar berupa kain-kulit yang dapat menjadi sebuah komoditi yang dapat diproduksi secara masif dengan menggunakan mesin dan handmade dibawah naungan suatu badan usaha, jika berbahan dasar non kainkulit akan sulit memenuhi konsistensi bentuk dalam produksi terutama yang hanya mengandalkan produksi dengan handmade dan dilakukan dalam bentuk bisnis perseorangan. Beberapa komoditi ternama yang memproduksi dan menjual berbagai kostum dan aksesoris cosplay berbahan dasar kain-kulit antara lain brand 'Monenjoy', '1/3 Delusion', dan 'DokiDoki SR'.

\section{Doktrin Fair Use dalam Cosplay}

Doktrin Fair Use merupakan sebuah doktrin yang berkonsep tentang pembatasan hak cipta, yang lebih lengkapnya merupakan sebuah pembatasan mengenai penggunaan karya cipta tanpa izin si penciptanya. Doktrin fair use juga dapat didefinisikan sebagai doktrin atau prinsip yang memperbolehkan pihak lain untuk menggunakan sebuah ciptaan/karya atas hak cipta tertentu untuk kepentingan dan tujuan yang spesifik.

Istilah Fair Use juga dikenal dengan sebutan penggunaan yang wajar. Kepentingan yang wajar yang dimaksid ialah kepentingan yang didasarkan pada keseimbangan dalam menikmati manfaat ekonomi atas suatu ciptaan. Ketentuan kepentingan yang wajar tercantum dalam pasal 44 ayat 1 dan Pasal 46 UU Hak Cipta.

Pasal 44: (1) Penggunaan, pengambilan, Penggandaan, dan/atau pengubahan suatu Ciptaan dan/atau produk Hak Terkait secara seluruh atau sebagian yang substansial tidak dianggap sebagai pelanggaran Hak Cipta jika sumbernya disebutkan atau dicantumkan secara lengkap untuk keperluan:

a. pendidikan, penelitian, penulisan karya ilmiah, penyusunan laporan, penulisan kritik atau tinjauan suatu masalah dengan tidak merugikan kepentingan yang wajar dari Pencipta atau Pemegang Hak Cipta;

b. keamanan serta penyelenggaraan pemerintahan, legislatif, dan peradilan;

c. ceramah yang hanya untuk tujuan pendidikan dan ilmu pengetahuan; atau

d. pertunjukan atau pementasan yang tidak dipungut bayaran dengan ketentuan tidak merugikan kepentingan yang wajar dari Pencipta

Pasal 46: (1) Penggandaan untuk 
kepentingan pribadi atas Ciptaan yang telah dilakukan Pengumuman hanya dapat dibuat sebanyak 1 (satu) salinan dan dapat dilakukan tanpa izin Pencipta atau Pemegang Hak Cipta; (2) Penggandaan untuk kepentingan pribadi sebagaimana dimaksud pada ayat (1) tidak mencakup:

a. karya arsitektur dalam bentuk bangunan atau konstruksi lain;

b. seluruh atau bagian yang substansial dari suatu buku atau notasi musik;

c. seluruh atau bagian substansial dari database dalam bentuk digital;

d. Program Komputer, kecuali sebagaimana dimaksud dalam Pasal 45 ayat (1); dan

e. Penggandaan untuk kepentingan pribadi yang pelaksanaannya bertentangan dengan kepentingan yang wajar dari Pencipta atau Pemegang Hak Cipta.

Berdasarkan Penjelasan Pasal 44 ayat (1) dan Pasal 46, penggunaan yang wajar tidak hanya didasarkan pada tujuan komersial atau tidak, tetapi apakah itu membahayakan kepentingan wajar pemegang hak cipta atau tidak. Jadi, secara tidak langsung dapat dimaknai seolah penyebaran dan produksi atas suatu karya hak cipta yang dilakukan atas dasar bukan untuk mencari keuntungan, tetapi jika tindakan tersebut merusak kepentingan ekonomi yang masuk akal dari pemegang hak cipta; maka itu dapat dianggap sebagai pelanggaran Hak Cipta.

Undang-undang Indonesia tentang penggunaan yang wajar dapat dianggap tidak jelas karena batasan pasti dari kepentingan yang wajar dari Penulis atau Pemegang Hak Cipta tidak jelas yang mana dalam undang-undang hak cipta itu sendiri tidak memiliki aturan yang jelas dan masih kabur mengenai prinsip Penggunaan yang Adil (Sari, 2015). Berdasarkan undangundang di atas, dapat dilihat bahwa apa yang dimaksud dengan "kepentingan wajar" adalah kepentingan yang berkaitan dengan kepentingan ekonomi pencipta atau pemegang hak cipta, yang manfaatnya dapat diterima oleh pencipta atau pemegang hak cipta dari ciptaan mereka.

Penggunaan sebuah karya hak cipta yang digunakan secara gratis atau direproduksi diatur dalam konvensi Berne yang berisi tentang aturan umum dan bukan pembatasan eksplisit atau pengecualian. Article 9 (2) Konvensi Berne menyatakan bahwa negara-negara anggota dapat menyediakan reproduksi gratis dalam kasus-kasus tertentu dimana tindakan tersebut tidak bertentangan dengan eksploitasi normal suatu karya dan secara tidak layak merugikan kepentingan pemilik (WIPO, 2016).

Article 9 (2): It shall be a matter for legislation in the countries of the Union to permit the reproduction of such works in certain special cases, provided that such reproduction does not conflict with a normal exploitation of the work and does not unreasonably prejudice the legitimate interests of the author.

Berdasarkan Article 9 (2) juga dikenal dengan istilah three step test yang menjadi sebuah tes dalam mengkaji suatu tindakan reproduksi atas suatu karya yang dilindungi oleh hak cipta. Mengkaji fenomena cosplay khsuusnya dalam memproduksi sebuah kostum dan aksesoris Cosplay dengan 
menggunakan three step test dari Article 9(2) Berne Convention

Pertama, Ketentuan 'special cases' terhadap cosplay yaitu apabila kostum dan aksesoris cosplay diproduksi untuk kepentingan pribadi. namun Apabila di terdapat aspek finansial yg didapatkan, tidak menganggung prospek bisnis utama dari si pemilik desain cosplay atau pemegang lisensi terkait ataupun menjadi pelaku usaha yang sejenis berdasarkan ketentuan perundangundangan yang berlaku.

Kedua, Ketentuan 'provided that such reproduction does not conflict with a normal exploitation of the work' berupa dalam membuat sebuah kostum dan aksesoris untuk cosplay alangkah baiknya dalam proses produksinya diberikan aspek yang membedakan dari desain karakter yang sedang diadaptasi kedalam bentuk kostum atau aksesoris baik yang telah mendapatkan izin atau tak berizin, sehingga terdapat nilai kreatifitas dalam membuat kostum dan aksesoris untuk cosplay tersebut dan tidak identic sama persis dengan kostum dan aksesoris yang dimiliki oleh pihak resmi/pemegang lisensi/penciptanya.

Terakhir, ketentuan 'does not unreasonably prejudice the legitimate interests of the author' yaitu dalam bercosplay ataupun membuat kostum cosplay yang berizin atau tak berizin, disarankan untuk tidak memberikan pengaruh terhadap kepentingan utama dari pihak resmi/pemegang lisensi/pencipta desain karakter tersebut khususnya kepentingan dalam aspek bisnis. Tetapi, melalui kegiatan bercosplay dapat membantu meningkatkan promosi dan marketing atas karya dari pihak resmi/pemegang lisensi/pencipta desain karakter tersebut agar lebih dikenal oleh masyarakat dan menjadi suatu bentuk apresiasi dari para penggemar atas karyakarya para penciptanya.

Apabila cosplay mendapatkan perlindungan dari hak cipta maupun hak desain industri ataupun sebaliknya, Alangkah lebih baiknya seorang cosplayer ataupun seseorang yang mendapatkan keuntungan finansial dari kegiatan cosplay harus tetap memperhatikan kepentingan yang wajar seperti halnya hasil kajian three step test diatas. Dalam kegiatan cosplay seorang cosplayer ataupun pelaku usaha yang bergerak dibidang cosplay harus menghormati seluruh hak ekonomi dan hak moral dari pemilik desain karakter yang di cosplaykan berupa menyebutkan nama pencipta desain tersebut jika diketahui atau menyebutkan nama judul karya dari tokoh karakter yang sedang dicosplaykan.

\section{PENUTUP \\ KESIMPULAN}

Cosplay 'Costume \& Play' merupakan sebuah istilah yang mendeskripsikan kreatifitas berkarya seseorang dengan menciptakan serta menggunakan sebuah kostum beserta aksesoris hingga bermain suatu peran berdasarkan refrensi dari karakter tokoh fiksi dari karya buku komik, film animasi dan video game. Kostum dan aksesoris yang digunakan untuk cosplay pada dasarnya merupakan hasil karya dari intelektual manusia yang sepatutnya dapat dilindungi oleh hak kekayaan inteletual. Secara eksplisit, kostum tidak disebutkan dalam UU Hak Cipta sebagai objek yang dilindungi. Tetapi jika dilihat dari proses pembuatan 
kostum cosplay, dapat dimungkinkan kostum beserta aksesoris cosplay dapat digolongkan sebagai karya seni terapan dan karya hasil adaptasi ciptaan yang mana karya seni terapan dan adaptasi ciptaan merupakan objek dari UU Hak Cipta pada Pasal 40 ayat 1 huruf g dan huruf n. Cosplay sebagai sebagai karya seni terapan, karena beberapa kostum dan aksesoris cosplay dibuat dengan menggunakan bahan utama non kain yang pada permukaanya diberikan sentuhan motif dan ornament. Cosplay sebagai tergolong sebagai karya adaptasi ciptaan, karena dalam proses pembuatan kostum dan aksesoris cosplay dilakukan dengan pengalihanwujud dari sebuah rancangan sketsa/gambar suatu kostum atau desain karakter menjadi sebuah kostum yang dapat digunakan secara nyata.

Doktrin Fair Use merupakan sebuah pembatasan mengenai penggunaan karya cipta tanpa izin si penciptanya dan dapat terhindar dari suatu pelanggaran dengan tetap memperhatikan hak moral dan hak ekonomi yang dimiliki. Fenomena popculture cosplay dalam praktiknya para cosplayer menggunakan kostum dan aksesoris cosplay yang dihasilkan adaptasi suatu refrensi desain gambar/sketsa karakter dari tokoh fiksi dari buku komik, film animasi atau video games. Hak atas desain gambar/sketsa karakter tokoh fiksi tersebut pasti dimiliki oleh si pemegang hak cipta tersebut atau pemegang lisensi dari karakter tokoh fiksi tersebut yang digunakan oleh para cosplayer atau pelaku bisnis sebagai refrensi untuk membuat kostum dan aksesoris cosplay yang kemudian digunakan secara pribadi atau digunakan untuk mendapatkan suatu keuntungan secara finansial. Doktrin fair use dapat di implementasikan dalam cosplay dengan merujuk Article 9(2) Berne Convention dan Pasal Pasal 44 ayat (1) dan Pasal 46 UU Hak Cipta perihal kepentingan yang wajar. Kepentingan yang wajar dalam cosplay diimplementasikan dengan menggunakan three step test dari Article 9(2) Berne Convention yaitu yang pertama cosplay digunakan dan diproduksi untuk kepentingan pribadi. Kedua, Dalam produksi menciptaan kostum cosplay harus terdapat aspek yang mebedakan dari bentuk yang direfrensikan agar terdapat nilai kreatifitas. Terakhir, seluruh kegiatan cosplay yang terjadi tidak menganggung kepentingan utama dari para pemegang hak cipta atau pemegang lisensi yang terlibat khususnya dalam bidang ekonomi-bisnis.

\section{SARAN}

Pemahaman masyarakat umum, penggiat cosplay dan pelaku bisnis cosplay yang memahami bahwa cosplay merupakan sebuah kegiatan yang berada zona 'abu-abu' perihal hukumnya, harus segera ditingkatkan pemahaman tersebut dengan mempelajari tentang hak kekayaan intelektual yang dimiliki suatu karya kostum khusus dalam hal hak cipta dan desain industri secara pribadi atau dengan bantuan dari akademisi dan praktisi yang memahami tentang hak kekayaan intelektual agar para penggiat cosplay khususnya yang mendapatkan keuntungan finansial dari cosplay dapat menghormati segala hak moral, hak ekonomi yang dimiliki dan dapat mewaspadai segala kemungkinan kerugian yang disebabkan atas pelanggaran HKI yang dapat terjadi di masa depan karena kegiatan cosplay. 


\section{DAFTAR PUSTAKA}

Bonnichisen, H. (2011). Cosplay: Creating or Playing Identities. Stockholm University.

Brown, J. (1997). Comic Book Fandom and Cultural Capital. Journal of Popular Culture, 30.

DJKI. (2013). Buku Panduan Hak Kekayaan Intelektual. Kementerian Hukum dan Hak Asasi Mansuia Republik Indonesia Direktorat Jenderal Hak Kekayaan Intelektual.

DJKI. (2020). Modul Kekayaan intelektual Hak Cipta. Kementerian Hukum dan Hak Asasi Manusia DIrektorat Jenderal Kekayaan Intelektual.

DJKI. (2020). Modul Kekayaan intelektual Lanjutan. Kementerian Hukum dan Hak Asasi Manusia Direktorat Jenderal Kekayaan Intelektual.

Fukiko, M. (2008). Cosupure Naze Nihonjin ha Seifuku ga Suki na no (Shoudensha Shinso). Tokyo.

Kartika, R. S. (2017). Perlindungan Hukum Costume Play (cosplay) terhadap Hak Cipta Karakter Animasi dan komik. Jember: Skripsi: Universitas Jember.

Madonia, M. R. (2016). All;s Fair in Copyright and CostumesL Fair Use Defense to Copyright Infrigment in Cosplay. Marquette Intellectual Property Law Review Vol.20, 178.

Sari, R. (2015). Penerapan Prinsip Fair Use dalam hak Cipta terkait Kebijakan Perbanyakan Buku di perustakaan Perguruan Tinggi (Studi Perbandingan Hukum Berdasarkan Undang-Undang Hak Cipta di Indonesia Nomor 28 Tahun 2014 dan Australia). Malang: Universitas Brawijaya.

Tabrani. (2005). Bahasa Rupa. Bandung: Penerbit Kelir.

Wang, K. (2010). Cosplay in China: Popular CUlture and Youth Community. Center for Eas and South-East Asian Studies, 18.

WIPO. (2016). Understanding Copyright and Related RIght. Switzerland: World Intellectual Property Organization.

Zainuddin, I. (2010). Wacana Desain. Bandung: Penerbit ITB. 